\title{
Impressive Tool to Communicate in Modern World is the Language English
}

\author{
Poonam G. Hingne, Member, IEDRC
}

\begin{abstract}
Today, almost each and every person realizes the importance of English Language for the sake of development in the walk of life. In fact, a working knowledge of English has become a requirement in number of different domains, occupations and professions. At number of schools and Universities, English is compulsory subject for students up to graduation for it is considered to be a useful tool to acquire knowledge, skills and to bring about fruitful interaction. It, thus, brings remote people nearer by means of modern technology and provides the best medium to interact with outside the region, state and country. Hence, through this paper it has been proved that not only English sounds as a universal subject discipline but also a global language.
\end{abstract}

Index Terms-Global language, international status, language teaching, window to the modern world.

\section{INTRODUCTION}

As English is becoming a global language [1], proficiency in English is considered essential for personal and professional development of a person. It goes without saying that the language plays an important role in the mental, emotional and social development of o person [2], [3]. Though English is a foreign language yet it occupies a unique position in our country.

Every language is the pride of the people who use it. No doubt, English has become a universal language [4]. A language which is known all over the countries. In India also, it has occupied an important role. In every sphere of life whether social, political, academic, cultural, economic, scientific and technological development it holds significant value [5], [6]. English language helps us in bringing closer to the rest of the world. Without it, an individual would become an isolated island in the ocean. It is impossible to disagree with Nehru's words: "English is our major window on the modern world "[7].

\section{RATIONALE}

The most commonly used medium to express oneself is language. English being an international language is used in all the spheres of human life. English play a vital role in development of an individual [8], [9]. The language helps to develop one's personality. Students can grab the opportunity by having fluency and command on English language [10], [11].

Manuscript received March 11, 2013; revised May 16, 2013.

Poonam G. Hingne is with the Department of Humanities and Basic Sciences, Datta Meghe Institute of Engineering, Research \& Technology, Wardha, India (e-mail: Hingnepoonam@Gmail.Com).
Objectives of the Study of English Language:

- English is taught as a compulsorily language in most of the states in the country.

- No language, ancient or modern can be compared with English in respect of it its international status.

- English is to be taught through oral practice most of the times. To master a language it is important to master it orally.

- While learning English, due importance should be given to all the four language skills; listening, speaking, reading and writing. Simultaneously English is taught principally as a language of comprehension.

- Comprehending English is mainly a matter of understanding, the basic grammar and structure of the language and widening the vocabulary.

\section{INITIAL STEPS TO LEARN THE LANGUAGE}

The objectives of teaching English language are basically related to Cognitive and Psychomotor domain. The language is a media of communication which involves the basic skills of reading, writing, listening and speaking. These skills are related to psychomotor domain. The categories of Cognitive and Psychomotor domain are used in identifying the objectives of teaching English language:

- The learner is able to understand the rules of Eng. Language or grammar. (Cognitive Objective)

- The learner is able to speak Eng. language correctly. (Psychomotor Objective)

- The learner is able to write Eng. language correctly. (Psychomotor Objective)

- The learner is able to read Eng. language correctly. (Psychomotor Objective)

1) Ability to understand English language

- To recognize English sounds without errors.

- To draw meaning from what he/she have listen.

2) Ability to speak English language

- Skill to pronounce with right intonation and stress.

- Skill to respond in speech as a reaction to hearing.

- Skill to speak at a normal speed.

3) Skills to write English language

- Skills to form letters.

- Skill is to spell words.

- Skill is to select right words.

- Skill is to construct sentences.

4) Ability to read English language

- Ability is to read simple prose, poetry, story, articles and comprehension. 
- Ability is to read simple sentences with understanding.

\section{PRINCIPLES OF LANGUAge Teaching}

\section{A. Principle of Naturalness}

A language is learned in a natural way; therefore mother is considered the first teacher and equivalent to hundred teachers. The following rules should be followed in a language teaching.

- Language teaching should start orally or speaking.

- A unit of language is a sentence not the words; therefore teacher should proceeds towards sentences.

- Second stage is to proceed from speaking to written teaching.

- In speaking or oral teaching a student should listen attentively. Listening is an important skill.

\section{B. Principle of Learning by Doing}

The main focus of language teaching is to develop the four skills -reading, writing, speaking and listening.Therefore practice and pronunciation drill is essential in language teaching Model reading, imitation reading, silent reading, writing, spelling are the essential activities for teaching language.

\section{Principle of Practice}

The practice o a language develops mastery of language, efficiency and fluency of a language. The expression, grammar and vocabulary depends continuous practice and use of a language.

Thorndike states that language is skill which depends on a continuous practice i.e. law of exercise works well.

\section{Principle of Imitation}

A language is learnt through natural imitation. A student learns or acquires the style of speaking and writing as demonstrated by his teacher. It is very essential that teacher, pronunciation, spellings and use of grammar should be imitated correctly.

\section{E. Principle of Motivation and Interest}

To learn the language it requires motivation and one has to develop interest towards it.

Herbert has suggested the following rules for making the teaching interesting and ever-lasting:

- New awareness should be based on previous knowledge.

- There should be variation in teaching lesson otherwise it would be monotonous.

- The questioning technique should be used to make students active and to keep them involved.

- Teaching should be experience based and activity centered.

- Students correct responses should be immediately reinforced and wrong responses should be ignored.

\section{The Globalization OF ENGLish}

English has_been widely accepted as the most wide spread language in the world. It is the first language for many countries around the planet from UK and Ireland to the USA, from Canada to Australia and New Zealand, from Guyana to Jamaica plus others.

As a second language it is also widespread in countries like Central and Eastern Europe and English is taught as a part of multilingual education in India, South Africa, Singapore and others .However, the number of people who speak English with at least some degree of proficiency exceeds any other language and its phenomenal advance around this planet is unparallel.

This is particularly important for students as this indicates that English will be of more use internationally than any other language. English is the prime means for communication \& can often serve as the Global language between two people from different cultures where in English is not the native tongue for example French engineer communicated with the Indian Engineer during the resent building construction at the Cairo Subway.

\section{Why ENGLISH IS A GLOBAL LANGUAGE}

A language achieves a genuinely global status when it develops a special role that is recognized in every country. The notion of 'special role 'has many facets. Such a role will be most evident in countries where large number of the people speaks the language as a mother tongue - in case of English.

However, no language has ever been spoken as a mother tongue in majority of the countries as English is used. But, mother tongue use by itself cannot give a language a global status .To achieves such a status; a language has to be taken up by other countries around the world. They have to decide to give it a special place within their communities. There are two main ways in which this can be done.

Firstly, a language can be made the administrative and official of communication language of a country, to be used as a medium of communication in such domains as Government, the law courts, the media and the educational system. To get on in these societies, it is essential to master the official language as early in life as possible. The role of an official language is today best illustrated by English which has now some kind of special status in near about seventy countries like (Ghana, Nigeria, India, Singapore etc). This is far more than the status achieved by any other language - though French, German, Spanish, Russian and Arabic are among those which have also developed a considerable official use.

Secondly, a language can be made a priority in a country's foreign- language teaching. It becomes the language which children are most likely to be taught when they arrive in school and the one most available to adults.

\section{ENGLISH AS A WINDOW ON MODERN WORLD}

The Radhakrishnan University Education Commission observed that English is a Language which is rich in Literature, humanistic, scientific \& technical. If under sentimental urges we should give up English, we would cut ourselves off from the living stream of ever growing knowledge. F.G. French has rightly said, "it is only through this language we have distilled essence of modern knowledge in all fields of human activities. 
Anyone who can read English can keep in touch with the whole world without leaving his own house.

Take for example: The strides in space technology .Its impact on everyday life are self-evident. The remote controls, cordless phones, satellite communications are the examples. Without adequate knowledge of English it is very hard to keep up, understand and absorb the developments in this field. Indian Space programmers would come to a standstill without English educated Scientists, Technicians and Engineers. A constant touch with the outside world is absolutely necessary for bringing about the revolutionary changes in the fields of agriculture, medicines, industry, telecommunications, transport and basic research system. English is the only language through which we can bring in the wonders at our doorsteps.

English has been rightly described as a window on the rapid progress of technology and scientific knowledge that is constantly taking place in the world. English is our major window on the modern world by closing this window we will turn back the clock of modernization.

\section{RESEARCH AND FINDINGS}

\section{A. A Study of Communicative Approach of Teaching English to STD. VIII}

Significance and Need of the Study: The study undertaken for research is important because it will help the teachers of English to develop and improve their methods of teaching and improvement in communicative acquisition skills of the learners.

\section{B. Objectives of the Research}

- To study the communicative approach for teaching English to Std .VIII in Wardha district.

- To study difficulties of using communicative approach to Std. VIII in Wardha district.

- The research is restricted to Std. VIII Marathi Medium teachers only.

- To suggest ways and means to improve the Communication skills in the teaching English.

\section{Research Procedure}

The Researcher has selected Descriptive- Survey Method as the method of study. The survey method is classified into different methods of study.

\section{Major Findings and Conclusions of the Research}

- Majority of the teachers uses English language to talk with their colleagues.

- Most of the teachers uses Communicative Approach to teach English language to Std.VIII

- Almost all the teachers use teaching aids like audio / visual aids, in their classroom while teaching as per its need.

- Maximum times make use of 'question- answer method' to get positive feedback.

- To develop speaking skill of the students, teacher use 'Group Discussion', 'Speak On a Topic ‘, 'Picture Lessons " and 'Short Conversation'.

- Almost all the teachers evaluate the reading skill of the students by asking them for loud reading.

- Most of the teachers use Direct Method to develop listening skill with the help of Audio - Visual Aids.

- Most of the teachers develop writing skill of their students by asking them to write story with given points and by taking Essay Competition.

- Almost all the teachers have the problems of Bilingual method i.e. students affection towards their mother tongue and students poor response about improving vocabulary and their own expression power.

\section{CONCLUSION}

English language is recognized as the important element in the education of modern world. Yet, there seems to be limited implementation of English courses globally, despite its current Lingua Franca status. The incorporation of English language and communication improvement courses will definitely play a vital role in the process of learning. A difference in approach from the current 'Start at the beginning Again 'or remedial solutions is needed when English ceases to be an examination subject and assumes the role of instrument of Communication.

\section{REFERENCES}

[1] D. Crystal, English as a Global Language, Cambridge University Press, 2rd Edition, 2003.

[2] D. Prasad, The Functional Aspects of Communication Skills, 2011-2012.

[3] A. K. Jain, P. S. Bhatia, and A. M. Sheikh, Professional Communication Skills, 2009

[4] M. J. Riemer, "English \& communication skills for the global engineer," Global Journal of Engineering Education, vol. 6, no. 1, published in Australia, pp. 91-99, 2002.

[5] V. Kazamia, "Training engineers on communication skills in English," SEFI, $40^{\text {th }}$ annual conference, Thessaloniki, Greece, 23-26 September 2012.

[6] R. Murphy, Essential English Grammar, Cambridge University Press, 1st Edition, 2012.

[7] R. A. Sharma, Language and Literature Teaching, 1st Edition, 2007, ch.1, 2, 3, pp. 1-69.

[8] G. A. Mudegaonkar and S. S. Pathak, "Communicative approach for teaching English," International Research Journal, vol. 1, no. 3, 4, pp. 65-67, Dec. 2009-Jan. 2010.

[9] S. S. C Board Pune, 2007 English Reader A Course Book in English Std, VIII, Pune: Maharashtra State Board of Secondary and Higher Secondary Education.

[10] S. S. C Board Pune, 2008 Kumarbharti, A Course Book in English, Maharashtra State Board of Secondary and Higher Secondary Education.

[11] A textbook of English, Mumbai 2013: Maharashtra State Board of Technical Education, Mumbai.

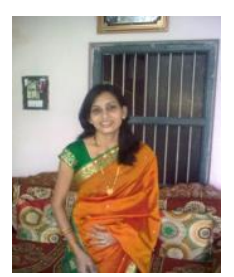

Poonam G. Hingne is a lecturer of English at Polytechnic in Datta Meghe Institute of Engineering, Technology \& Research, Wardha (India) .Born on $12^{\text {th }}$ May 1984, She holds an MA ( English Literature) from Nagpur University. She has also completed graduation in (Eng .Lit) \& degree of Bachelor in Education. Apart from that she has achieved one year diploma degree in Aviation and Hospitality from Frankfinn Institute. Besides that she has done one year diploma in French language .Her area of interest includes the study of Eng. Literature from early to the contemporary, various Novels and Poetries of renowned authors. She has four years of teaching experience at school level as well as Diploma level. Presently a member of IEDRC. 